\title{
A new species of rock-dwelling hylid frog (Anura:Hylidae) from the eastern Kimberley region of Western Australia
}

\author{
Paul Doughty ${ }^{{ }^{*}}$ and Marion Anstis ${ }^{2}$ \\ ${ }^{1}$ Department of Terrestrial Vertebrates, Western Australian Museum, \\ 49 Kew Street, Welshpool WA 6106, Australia \\ *corresponding author - e-mail: Paul.Doughty@museum.wa.gov.au \\ 226 Wideview Road, Berowra Heights NSW 2082, Australia
}

\begin{abstract}
Australia's documented frog diversity slowly continues to grow owing to genetic tests for cryptic species and ongoing exploration of remote regions. Recent collecting trips in Western Australia's east Kimberley region resulted in the discovery of a new rock-dwelling hylid frog, Litoria staccato $\mathrm{sp}$. nov. The new species is closely related to the much more widely distributed $L$. coplandi, which also breeds in the same rocky creeks. Litoria staccato sp. nov. is a small to moderate-sized frog characterised from cooccuring species by a combination of a moderately pointed snout, expanded terminal discs, half-webbed toes and a mottled appearance with variable colouration (reddish brown, grey or beige). The advertisement call consists of a rapid burst of irregularly-spaced notes, followed by groups of softer calls comprised of single or complex notes. Compared to L. coplandi, L. staccato sp. nov. is slightly smaller, has reduced webbing between the toes, different colouration and pattern (including diffuse vertebral and dorsolateral stripes), reduced glandular tissue at the angle of the jaw and a highly divergent call. Tadpoles show some adaptations to stream-living but also have body shape affinities associated with ground hylid pond-dwelling types such as $L$. inermis. The new species has only been found near Wyndham in the far north of Western Australia, and no specimens have been detected in existing museum collections indicating a restricted distribution. Owing to its remoteness and complex geology, the Kimberley region may hold other undiscovered rock-dwelling species with small natural ranges.
\end{abstract}

Key words: frog, Kimberley, Litoria, rock-dwelling, tadpole

\section{INTRODUCTION}

Frogs of the genus Litoria are prominent among northern Australian vertebrate fauna. Here they have radiated into a diversity of forms specialized for different lifestyles, including species that are strongly associated with rocky streams and pools along escarpments. There are currently three small rock-dwelling hylids from the humid Kimberley to Arnhem Land region of northern Australia: $L$. coplandi, L. personata and L. meiriana. All three species have expanded terminal discs on their fingers and toes and are encountered along rocky creeks, water holes and escarpments. Tyler and Davies (1978) initially placed L. coplandi in its own monotypic species group. Barker et al. (1995) placed the rock-dwelling forms either directly in a " $L$. latopalmata" group (L. personata) or in "other Litoria" (L. coplandi and L. meiriana). Before being formally described, specimens of $L$. coplandi were placed in "L. latopalmata watjulumensis" but later described as a separate taxon by Tyler (1968a). Tyler et al. (1978) compared the new taxon L. personata to various $L$. latopalmata group members, but not to $L$. coplandi. Recent molecular work indicates that all three rock-adapted hylids may be only distantly related (S. Donnellan personal communication), suggesting that they evolved an association with flowing water and pools on rocks independently. Litoria meiriana is likely to be only distantly related to the other two species based on morphological (adults and tadpoles), behavioural and genetic differences (Tyler and Davies 1978; Tyler et al. 1983; S. Donnellan personal communication).

Potential threats to the native frogs of the tropical Kimberley region in Western Australia from introduced species such as the cane toad (Bufo marinus: Bufonidae) and chytrid fungus have generated concern about the future status of frogs there. As a result, new surveys are being conducted to estimate the true diversity of the region. Initial surveys conducted in the wet season of 2005-2006 in the east Kimberley have revealed a previously unknown taxon closely allied to, and syntopic with, the rock frog, $L$. coplandi. Here we describe this 
taxon as a new species and present information on the male advertisement call, embryonic and tadpole development and the breeding habitat.

\section{MATERIALS AND METHODS}

We examined 12 adult specimens of the new taxon and compared them with its suspected close allies $L$. coplandi and $L$. personata. Morphological measurements generally follow Tyler (1968b) with some modifications (see Table 1). Measurements that could be made on either side of the body (e.g., tarsus length) were measured on the right side of the animal, unless this was damaged or misshapen. Measurements were made under a Leica MZ6 dissecting scope with digital vernier callipers to the nearest $0.01 \mathrm{~mm}$. We also calculated the following ratios (see Table 1A for abbreviations): HL/HW, IN/ IO, EN/IN, TL/SVL, TarL/SVL and TarL/TL.

We compared the calls of two males of the new species with the call of one $L$. coplandi and one $L$. meiriana. Calls were recorded on a Marantz PMD670 digital recorder with a BeyerDynamic M88N microphone. Sound analysis was carried out on Cool Edit Pro and Raven 1.3b (Charif et al. 2004).

We collected a sample of embryos just prior to hatching close to where calling males and a gravid female had been collected the previous night. Six hatchlings and a small sample of capsules from the same clutch were also preserved. A sample of live hatchlings was collected and reared to metamorphosis to confirm identity. In addition, another sample of small tadpoles at stages 26-27 (Gosner 1960) found in the same pool and

Table 1 Characters measured with abbreviations and explanations.

Character Abbrev. Explanation of Measurement

\section{A. Adults}

Snout-vent length Inter-limb length

Head length

Head width

Eye-naris distance

Interorbital span

Internarial span

Eye diameter

Tympanum length

Forearm length

Hand length

Third finger disc width

Tibia length

Tarsus length

Foot length

Fourth toe disc width

\section{B. Tadpoles}

Total length

Body length

Body depth

Body width

Body width at eyes

Tail muscle depth

Tail muscle width

Tail depth

Dorsal fin depth

Tail muscle depth

Ventral fin depth

Inter-orbital span

Inter-narial span

Eye to naris

Narial diameter

Snout to spiracle

Snout to naris

Snout to eye

Eye diameter

Oral disc width
SVL From tip of snout to posterior tip of urostyle

ILL From axilla to groin

HL From tip of snout to posterior edge of tympanum

HW Width of head at centre of tympani

EN From anterior corner of eye to posterior edge of naris

IO Distance between anterior corners of eyes

IN Distance between inner edges of nares

NM Posterior edge of naris to upper edge of jaw

EL Anterior to posterior corners

TymL Anterior to posterior edges

FL Elbow to proximal edge of palmar tubercle

HandL Tip of $3^{\text {rd }}$ finger to proximal edge of palmar tubercle

$3^{\text {rdFDW }}$ Maximum transverse width of $3^{\text {rd }}$ finger disc

TL Measured with leg in natural resting position, from knee to tarsus

TarL Measured with leg in natural resting position, from proximal end of tarsus to proximal edge of inner metatarsal tubercle

FootL From tip of $4^{\text {th }}$ toe to proximal end of inner metatarsal tubercle

$4^{\text {thTDW }}$ Maximum transverse width of $4^{\text {th }}$ finger disc

$\begin{array}{ll}\text { TL } & \text { From tip of snout to tail tip } \\ \text { BL } & \text { From tip of snout to end of body } \\ \text { BD } & \text { Maximum height of body } \\ \text { BW } & \text { Widest point of body in dorsal view } \\ \text { EBW } & \text { Body width at level of eyes in dorsal view } \\ \text { BTM } & \text { Depth of tail muscle at base } \\ \text { BTMW } & \text { Width across tail muscle at base in dorsal view } \\ \text { TD } & \text { Measured at midpoint of tail } \\ \text { DF } & \text { Measured at tail depth } \\ \text { TM } & \text { Measured at tail depth } \\ \text { VF } & \text { Measured at tail depth } \\ \text { IO } & \text { Measured in dorsal view } \\ \text { IN } & \text { Measured in dorsal view } \\ \text { EN } & \text { Measured in dorsal view } \\ \text { N } & \text { Measured in dorsal view } \\ \text { SS } & \\ \text { SN } & \\ \text { SE } & \\ \text { ED } & \\ \text { ODW } & \end{array}$


considered likely to be this species, was collected and reared to metamorphosis. Tadpoles were reared in $50 \mathrm{~cm}$ diameter containers of stream water to a depth of $14 \mathrm{~cm}$, rocks and leaf litter from the stream where they were collected. Water was aerated and temperatures ranged from about 16 $36^{\circ} \mathrm{C}$ during development.

Tadpole descriptions follow Anstis (2002). Abbreviations for tadpole morphometric characters follow Anstis and Tyler (2005) and are given in Table 1B. Measurements were made with an ocular micrometer attached to a microscope and vernier callipers. Embryos and tadpoles were drawn with the aid of a camera lucida, and photographs of live tadpoles taken using a Nikon D70 and $60 \mathrm{~mm}$ macro lens.

\section{SYSTEMATICS}

\section{Family HYLIDAE Rafinesque 1815}

Genus Litoria Tschudi 1838

Litoria staccato sp. nov.

\section{Chattering Rock Frog \\ Figures 1-5}

\section{Holotype}

WAM R162611. Adult male collected near "The Grotto", $30 \mathrm{~km}$ south of Wyndham, Western Australia (15.72540 S, $128.27953^{\circ}$ E), by P. Doughty and C. Mills on 30 January 2006. Liver sample stored at $-75^{\circ} \mathrm{C}$ at the Western Australian Museum, Welshpool.

\section{Paratypes}

WAM R162512, R162514 (males) and WAM R162513 (female) collected 8 January 2006 by P. Doughty, J. Francis and M. Anstis $\left(15.71466^{\circ} \mathrm{S}\right.$, $128.27288^{\circ} \mathrm{E}$ ); WAM R162537-8 (males) collected on 15 January 2006 by P. Doughty, J. Francis and C. Mills (15.72506 ${ }^{\circ}$, $\left.128.27951^{\circ} \mathrm{E}\right)$; WAM R162612-6 (males) and WAM R162620 (female) collected on 30 January 2006 by $P$. Doughty and C. Mills $\left(15.72540^{\circ} \mathrm{S}, 128.27953^{\circ} \mathrm{E}\right)$. Liver samples stored at $75^{\circ} \mathrm{C}$ at the Western Australian Museum, Welshpool.

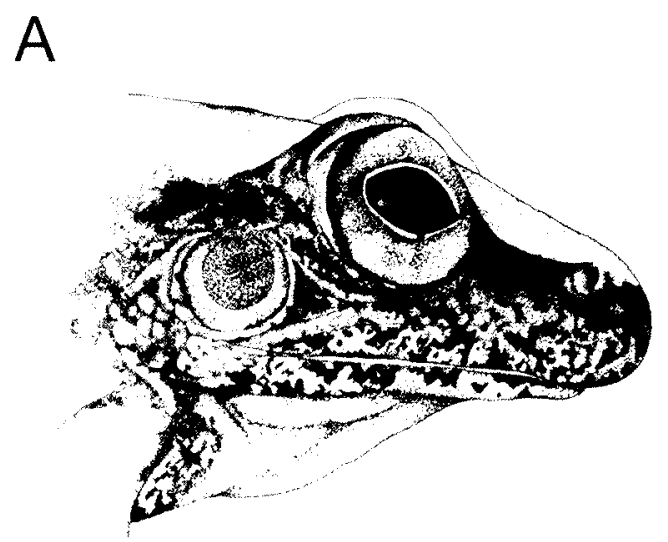

$\mathrm{B}$

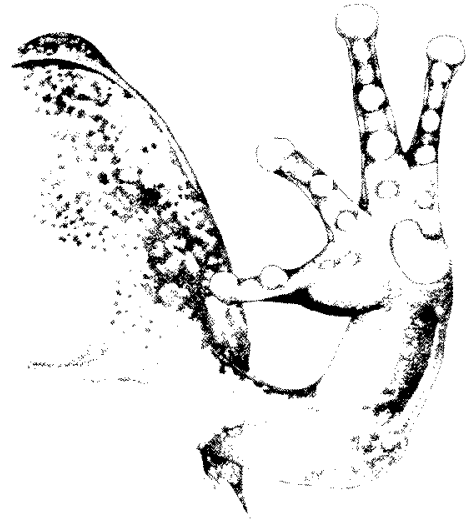

C

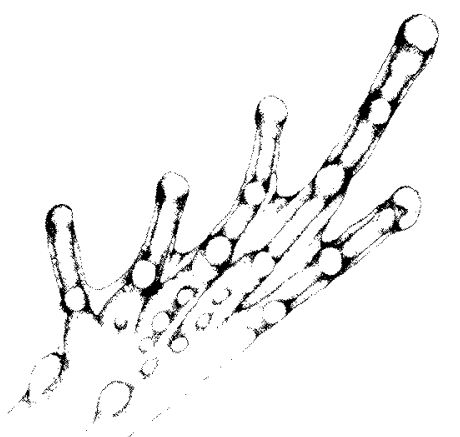

Figure 1 Head (A), chin and hand (B) and foot (C) of the male holotype of Litoria staccato (WAM R162611). 
Embryos and Tadpoles

WAM R162946-7 (embryos), WAM R162948-57 (tadpoles) collected 9 January 2006 by M. Anstis and P. Doughty $\left(15.71466^{\circ} \mathrm{S}, 128.27288^{\circ} \mathrm{E}\right)$.

\section{Diagnosis}

A small to moderate-sized rock-dwelling hylid with moderately pointed snout, medium build and slender limbs. Tips of fingers widely expanded and toes half-webbed. Dark lateral head stripe present but not clearly defined; pale triangular patch usually discernible on snout. Lateral head stripe continues beyond tympanum and fades posteriorly into broader mottled lateral stripe that demarcates lateral and ventral zones. Dorsal colour of males variable, ranges from reddish brown to slate grey to beige; females reddish brown. There are variably expressed diffuse darker vertebral, dorsolateral and lateral stripes.

Distinguishable from similar-sized ground hylid frogs of the Kimberley-Arnhem Land region by possession of broadly expanded discs on tips of fingers and toes (not $L$. inermis, L. latopalmata, $L$. nasuta or $L$. pallida which lack expanded terminal discs), toes half-webbed (not $L$. coplandi, $L$. meiriana or $L$. wotjulumensis which have fully webbed toes) and mottled dorsal colouration with diffuse lateral head stripe, vertebral and dorsolateral stripes (not $L$. personata which has strong lateral head stripe and uniform-coloured dorsum) (see also Comparison with other species, below). The male call consists of a series of rapid, high-pitched irregularly spaced notes, interspersed with short and complex softer calls (Figure 3C).

\section{Description of holotype}

Head narrow and triangular with moderately pointed snout and prominent eyes (Figure 1A). In profile, snout gradually narrows to oblique tip. Nares positioned on tip of snout under canthus rostralis, slightly oval, opening dorsolaterally and slightly forwards. Canthus rostralis straight with moderately sharp edge; loreal region steep-sided and concave. Tympanum prominent and circular, distinct annulus present except for dorsal edge. Small cluster of 5-6 glandular nodules between lower posterior edge of tympanum and insertion of forearm. Vomerine teeth a pair of smooth ridges anterior to medium-large oblique choanae. Tongue oval, tapers posteriorly, free edge blunt and unnotched.

Arms short and slender. Fingers long, slender and unwebbed but with weak lateral fringes (Figure 1B). Palmar tubercles at base of outer portion of wrist prominent and paisley-shaped (narrow end pointing towards fingers). Large tubercles present on finger joints with smaller tubercles on palm. Nuptial pad comprised of fine layer of small dark rugose tubercles on inner margin of $1^{\text {st }}$ finger.
Fingers in order of length: $3>4>1>2$. Tips of fingers with broad discs: $1^{\text {st }}$ and $2^{\text {nd }}$ fingers approximately $2 x$ wider, and $3^{\text {rd }}$ and $4^{\text {th }}$ fingers approximately $1.5 x$ wider than distal phalanx in life (in preservative, discs $1.5 x$ and $1 x$ wider, respectively).

Legs long and slender. Distinct fold of skin above knee. A fringe runs along inner tarsus and connects to inner metatarsal tubercle. Moderate sized inner metatarsal tubercle narrow, projects distally (Figure 1C). Outer metatarsal tubercle small and oval, projects towards toes. Feet narrow. Toes in order of length: $4>5>3>2>1$. Webbing between $1^{\text {st }}$ and $2^{\text {nd }}$ and between $2^{\text {nd }}$ and $3^{\text {rd }}$ toes to proximal end of distal phalanges on each toe. Webbing between $3^{\text {rd }}$ and $4^{\text {th }}$ toes to just beyond proximal joint of distal phalange on $3^{\text {rd }}$ toe, and to base of proximal end of penultimate phalanx on $4^{\text {th }}$ toe. Webbing between $4^{\text {th }}$ and $5^{\text {th }}$ toes to base of proximal end of penultimate phalanx on $4^{\text {th }}$ toe and to just above proximal end of distal phalanx on $5^{\text {th }}$ toe. Lateral fringes on all toes beyond webbing. Toe discs only slightly wider than penultimate phalanx in life (in preservative, approximately the same width). Medium conical subarticular tubercles on joints of toes with minute tubercles on plantar surface.

Skin on dorsum and limbs smooth. Belly granular with slight transverse crease between arms, towards anterior edge of arm insertion. Underside of posterior edge of thighs with larger flattened granulation. Coccyx forms prominent ridge that protrudes slightly beyond end of body. Cloaca positioned just below coccyx, projects dorsoposteriorly.

\section{Dimensions of holotype ( $\mathrm{mm}$ )}

SVL 30.5; ILL 13.15; HL 11.66; HW 10.83; EN 2.76; IO 5.3; IN 3.21; NM 1.64; EL 3.21; TymL 2.30; FL 6.15; HandL 7.60; $3^{\text {rd }}$ FDW 0.72; TL 15.72; TarL 8.40; FootL 11.69; $4^{\text {th }}$ TDW $0.56 ; \mathrm{HL} / \mathrm{SVL} 0.38 ; \mathrm{HL} / \mathrm{HW}$ 1.08; EN/IN 0.86; EN/IE 0.52; TL/SVL 0.52; TarL/ SVL $0.28 ;$ TarL/TL 0.53 .

\section{Colour in life}

Dorsum light reddish brown (Figure 2A). Faint, darker, narrow vertebral and wider dorsolateral stripes present, the latter forming a diffuse border between dorsal and lateral zones. Lateral head stripes dark grey, not sharply defined along snout, with diffuse dorsal and ventral edges. Lateral head stripe begins narrowly at rostrum passing through nostril and lower half of eye; continues posteriorly from eye through tympanum, extending just above dorsal edge of tympanum; angles downwards towards ventral surface, fading diffusely just over half-way between insertion of arms and legs; continues as diffuse mottled border between lateral and ventral zones. A subtle, yet distinct, paler triangular patch on snout is defined dorsally by border of lateral head stripes and posteriorly by 
A

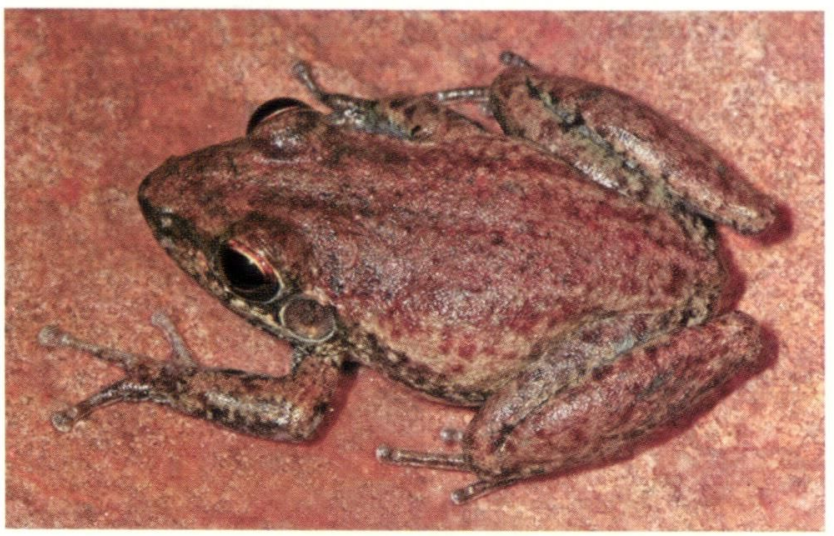

B

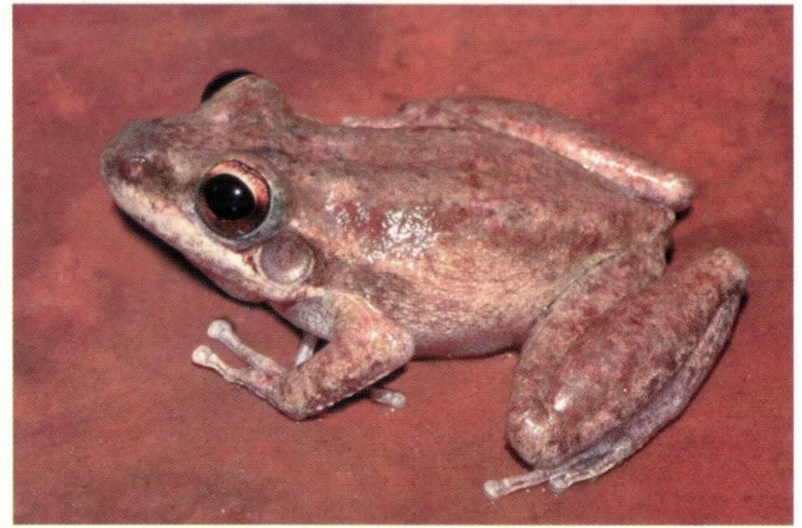

C

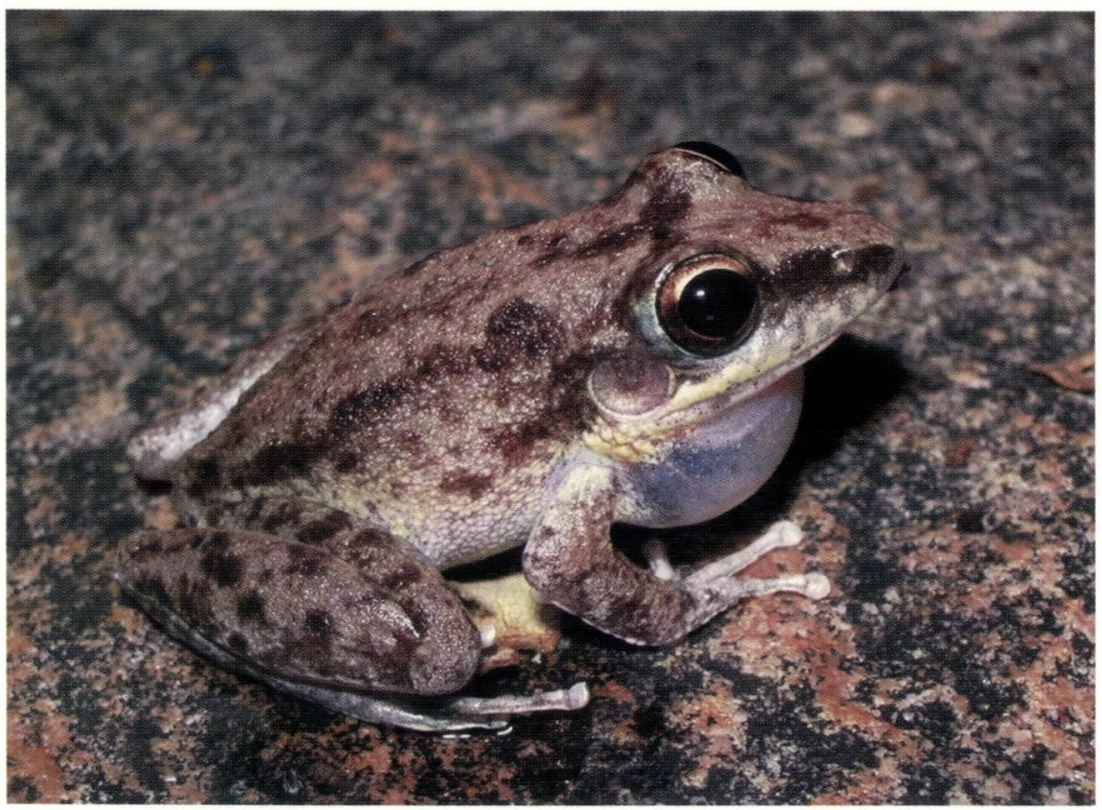

D

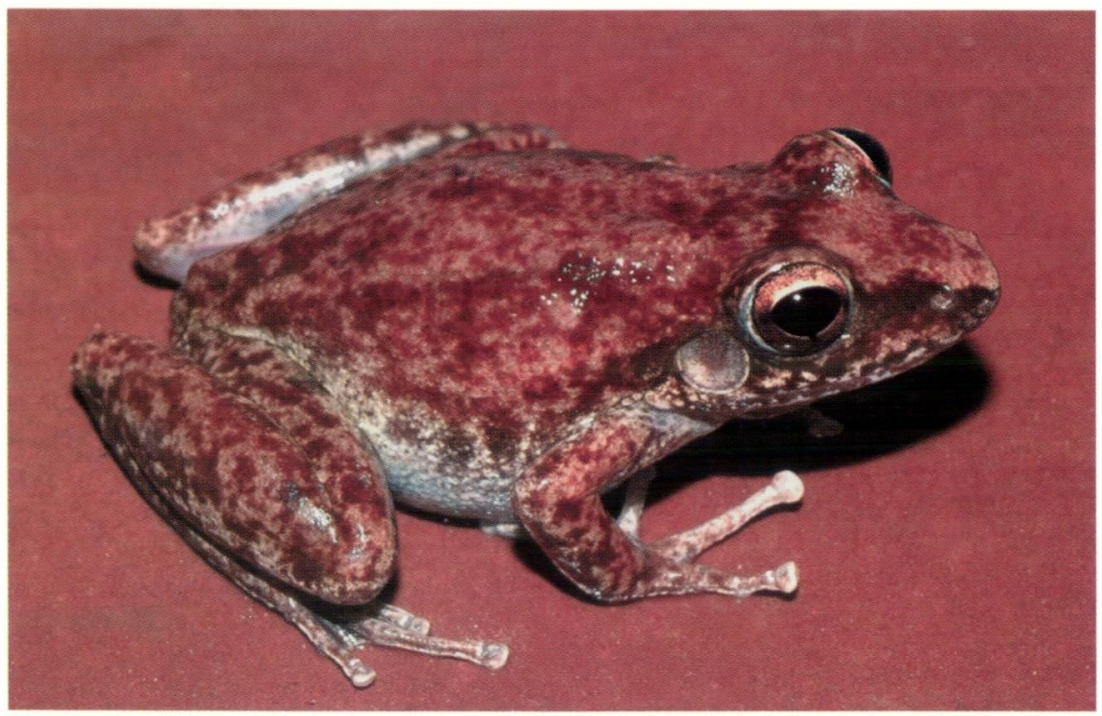

Figure 2 Adult frogs in life of Litoria staccato showing colour variation. A) holotype male (WAM R162611) with reddish brown colour; B) beige male (WAM R162514); C) calling slate grey male (uncollected); D) reddish brown female (WAM R162513). 
diffuse darker bar between eyes. As triangular patch narrows towards tip of snout, it broadens slightly and contacts nares before terminating just anterior to nares. Lateral head stripes continue forward to join at rostrum tip. Upper lip mottled with diffuse black. Lower lip pale with dark mottling not extending to chin. Chin darkly stippled anterior to vocal sac, and less stippled towards margin of jaw. Lower two-thirds of iris brown, upper third bright copper gold, pale gold border above pupil, less distinct below pupil.

Tympanum unpigmented except for darker patch extending from dorsal edge to centre. Annulus of tympanum pale. Pale lemon yellow wash over upper lip (below stripe), sides and posterior surface of thighs. Bright lemon yellow wash over groin, fades anteriorly. Flanks and posterior surfaces of thighs diffusely mottled with reddish brown colour of dorsum. Dorsal surface of limbs reddish brown (same as dorsum) with diffuse darker mottling. Dorsal surfaces of arms mottled, fingers paler, especially $2^{\text {nd }}$ and $3^{\text {rd }}$. Outer edge of forearms with darker mottling. Dorsal surface of legs dark with some mottling, especially on posterior edge of thighs where blotches form an uninterrupted line. Belly and ventral surface of limbs pale white, undersurfaces of feet dark brown.

\section{Colour in preservative}

Dorsal surfaces much darker than in life - dark slate to chocolate brown - with vertebral and dorsolateral stripes much less apparent. Dark lateral head stripe poorly defined with ground colour discernible beneath; continues past tympanum and fades on side near arms. Yellow wash in groin barely discernible. Undersurfaces pale yellow, hands and feet dark.

\section{Variation}

Male body sizes varied only slightly - the smallest was $29 \mathrm{~mm}$ and the largest $33 \mathrm{~mm}$ (Table 2). The build, proportions and general appearance of male specimens generally agreed with the holotype except for the following (WAM prefixes excluded below). Shape of rostrum varied from sharp and angular (R162614, R162616) to more broadly rounded (R162612). Glandular tissue at angle of jaw similar to holotype for most males, but in R162616, nodules were higher and more prominent, and in R162512, skin was nearly smooth. Nuptial pads ranged from less developed (lighter and less extensive; R162512) to very heavy and extensive (R162537). R162515 possessed slightly rougher pads than other males.

The two female specimens had lengths of 35.5 and $36.5 \mathrm{~mm}$ - larger than any of the 10 males. Both females were collected near calling males and were heavily gravid. Other than overall body size there were no obvious differences between males and
Table 2 Summaries of characters and ratios measured for Litoria staccato, $L$. coplandi and $L$. personata. Mean \pm S.D. (range). Sample sizes are for species unless noted. See Table $1 \mathrm{~A}$ for abbreviations.

\begin{tabular}{|c|c|c|c|}
\hline Character & $\begin{array}{c}\text { L. staccato } \\
\mathrm{N}=12\end{array}$ & $\begin{array}{l}\text { L. coplandi } \\
\mathrm{N}=56\end{array}$ & $\begin{array}{c}L . \text { personata } \\
\mathrm{N}=12\end{array}$ \\
\hline SVL & $\begin{array}{l}31.4 \pm 2.4 \\
(29-36.5)\end{array}$ & $\begin{array}{c}33.4 \pm 4.0 \\
(24.5-43.0)\end{array}$ & $\begin{array}{c}30.8 \pm 2.4 \\
(26.5-33.5)\end{array}$ \\
\hline ILL & $\begin{array}{c}13.0 \pm 2.1 \\
(10.4-18.4)\end{array}$ & $\begin{array}{c}13.8 \pm 2.1 \\
(8.8-18.0) \\
N=54\end{array}$ & $\begin{array}{c}12.3 \pm 1.9 \\
(9.5-15.3)\end{array}$ \\
\hline HL & $\begin{array}{c}11.3 \pm 0.7 \\
(10.4-13.1)\end{array}$ & $\begin{array}{l}(12.4 \pm 1.3) \\
(8.6-15.2)\end{array}$ & $\begin{array}{c}11.2 \pm 0.8 \\
(9.7-12.4)\end{array}$ \\
\hline HW & $\begin{array}{c}10.7 \pm 0.8 \\
(9.8-12.6)\end{array}$ & $\begin{array}{c}11.8 \pm 1.4 \\
(8.9-14.6)\end{array}$ & $\begin{array}{c}9.9 \pm 0.7 \\
(8.6-11.0)\end{array}$ \\
\hline $\mathrm{EN}$ & $\begin{array}{c}2.8 \pm 0.2 \\
(2.6-3.1)\end{array}$ & $\begin{array}{c}3.2+0.4 \\
(2.6-4.1)\end{array}$ & $\begin{array}{c}3.0 \pm 0.3 \\
(2.4-3.2)\end{array}$ \\
\hline 10 & $\begin{array}{c}5.4 \pm 0.3 \\
(4.8-6.0)\end{array}$ & $\begin{array}{c}6.6 \pm 0.7 \\
(5.0-8.2)\end{array}$ & $\begin{array}{c}5.9 \pm 0.5 \\
(5.0-6.5)\end{array}$ \\
\hline IN & $\begin{array}{c}3.2 \pm 0.2 \\
(2.8-3.6)\end{array}$ & $\begin{array}{c}3.2 \pm 0.4 \\
(2.4-4.1)\end{array}$ & $\begin{array}{c}3.2 \pm 0.2 \\
(2.9-3.4)\end{array}$ \\
\hline NM & $\begin{array}{c}1.8 \pm 0.2 \\
(1.5-2.1) \\
N=11\end{array}$ & $\begin{array}{c}2.1 \pm 0.3 \\
(1.6-2.7) \\
N=55\end{array}$ & $\begin{array}{c}1.7 \pm 0.2 \\
(1.5-1.9)\end{array}$ \\
\hline EL & $\begin{array}{c}3.2 \pm 0.3 \\
(2.8-4.0)\end{array}$ & $\begin{array}{c}3.7 \pm 0.4 \\
(2.9-4.5)\end{array}$ & $\begin{array}{c}3.3 \pm 0.4 \\
(2.6-4.0)\end{array}$ \\
\hline TymL & $\begin{array}{c}2.3 \pm 0.1 \\
(2.0-2.5)\end{array}$ & $\begin{array}{c}2.6 \pm 0.3 \\
(2.1-3.8)\end{array}$ & $\begin{array}{c}2.5 \pm 0.6 \\
(1.9-3.3)\end{array}$ \\
\hline FL & $\begin{array}{c}6.4 \pm 0.7 \\
(5.7-7.9)\end{array}$ & $\begin{array}{c}6.9 \pm 0.7 \\
(5.5-8.6)\end{array}$ & $\begin{array}{c}6.6 \pm 0.6 \\
(5.7-8.0)\end{array}$ \\
\hline HandL & $\begin{array}{c}7.6 \pm 1.2 \\
(6.0-9.6)\end{array}$ & $\begin{array}{c}8.4 \pm 1.3 \\
(5.8-10.3)\end{array}$ & $\begin{array}{c}7.7 \pm 0.6 \\
(6.6-8.5) \\
N=11\end{array}$ \\
\hline $3^{\text {rd }} \mathrm{FDW}$ & $\begin{array}{c}0.98 \pm 0.15 \\
(0.77-1.23) \\
N=8\end{array}$ & $\begin{array}{c}1.14 \pm 0.23 \\
(0.63-1.81) \\
N=45\end{array}$ & $\begin{array}{c}0.93 \pm 0.22 \\
(0.60-1.13) \\
N=8\end{array}$ \\
\hline TL & $\begin{array}{c}16.0 \pm 1.3 \\
(14.3-18.4)\end{array}$ & $\begin{array}{c}18.7+2.2 \\
(14.8-24.1)\end{array}$ & $\begin{array}{c}17.4 \pm 1.6 \\
(14.7-20.0)\end{array}$ \\
\hline TarL & $\begin{array}{c}8.4 \pm 0.6 \\
(7.4-9.7)\end{array}$ & $\begin{array}{c}9.1 \pm 1.1 \\
(7.4-11.4)\end{array}$ & $\begin{array}{c}9.2 \pm 1.0 \\
(7.2-10.6)\end{array}$ \\
\hline FootL & $\begin{array}{c}11.9 \pm 1.2 \\
(10.8-14.4)\end{array}$ & $\begin{array}{c}13.3 \pm 1.8 \\
(10.4-18.2) \\
N=55\end{array}$ & $\begin{array}{c}12.1 \pm 1.3 \\
(10.1-13.9)\end{array}$ \\
\hline $4^{\text {th TDW }}$ & $\begin{array}{c}0.73 \pm 0.10 \\
(0.63-0.94) \\
N=8\end{array}$ & $\begin{array}{c}0.98 \pm 0.25 \\
(0.58-1.68) \\
N=45\end{array}$ & $\begin{array}{c}0.72 \pm 0.21 \\
(0.48-1.04) \\
N=8\end{array}$ \\
\hline HW/SVL & $\begin{array}{c}0.34 \pm 0.01 \\
(0.31-0.36)\end{array}$ & $\begin{array}{c}0.36 \pm 0.01 \\
(0.32-0.36)\end{array}$ & $\begin{array}{c}0.32 \pm 0.01 \\
(0.32-0.36)\end{array}$ \\
\hline $\mathrm{HL} / \mathrm{HW}$ & $\begin{array}{c}1.05 \pm 0.03 \\
(1.02-1.10)\end{array}$ & $\begin{array}{c}1.04 \pm 0.05 \\
(0.82-1.16)\end{array}$ & $\begin{array}{c}1.13 \pm 0.04 \\
(1.07-1.21)\end{array}$ \\
\hline $\mathrm{EN} / \mathrm{IN}$ & $\begin{array}{c}0.89 \pm 0.04 \\
(0.81-0.95)\end{array}$ & $\begin{array}{c}0.98 \pm 0.08 \\
(0.81-1.16)\end{array}$ & $\begin{array}{c}0.93 \pm 0.06 \\
(0.82-1.04)\end{array}$ \\
\hline $\mathrm{EN} / \mathrm{IO}$ & $\begin{array}{c}0.52 \pm 0.02 \\
(0.47-0.56)\end{array}$ & $\begin{array}{c}0.48 \pm 0.04 \\
(0.41-0.57)\end{array}$ & $\begin{array}{c}0.50 \pm 0.04 \\
(0.45-0.57)\end{array}$ \\
\hline TL/SVL & $\begin{array}{c}0.51 \pm 0.02 \\
(0.46-0.55)\end{array}$ & $\begin{array}{c}0.56 \pm 0.04 \\
(0.45-0.65)\end{array}$ & $\begin{array}{c}0.57 \pm 0.03 \\
(0.49-0.60)\end{array}$ \\
\hline TarL/SVL & $\begin{array}{c}0.27 \pm 0.01 \\
(0.25-0.29)\end{array}$ & $\begin{array}{c}0.27 \pm 0.02 \\
(0.22-0.33)\end{array}$ & $\begin{array}{c}0.30 \pm 0.02 \\
(0.24-0.33)\end{array}$ \\
\hline TarL/TL & $\begin{array}{c}0.52 \pm 0.02 \\
(0.49-0.55)\end{array}$ & $\begin{array}{c}0.49 \pm 0.02 \\
(0.44-0.53)\end{array}$ & $\begin{array}{c}0.53 \pm 0.03 \\
(0.48-0.58)\end{array}$ \\
\hline
\end{tabular}


females in morphological characters, but the small number of females prevented further evaluation.

Colouration of males was variable. In addition to the reddish brown of the holotype and paratypes R162537-8, R162612 and R162616, other individuals were bright beige while active in life (R162514 and other uncollected males - Figure 2B). Still others were slate grey (R162512, R162613-5 - Figure 2C). Mottling on the dorsum was also variable - some individuals had darker mottling (e.g., R162612) while others had only faint variegations (e.g., R162514). Collected individuals changed colour from generally vivid while active to more dull and/ or mottled the following day, obscuring the diffuse vertebral, dorsolateral and lateral streaks.

The lateral head stripe ranged from relatively demarcated (e.g., R162613) to diffuse grey (e.g., R162514) with borders never sharply defined. In most males, the lateral head stripes did not meet at the tip of the snout, but in one other individual (R162537) they joined, as in the holotype. The paler snout patch outlined by the lateral head stripes and the diffuse posterior bar between the eves varied in definition from very clear (e.g., R162537) to poorly defined (R162612). Presence of the thin vertebral and wider dorsolateral streaks was highly variable. In some specimens, stripes were relatively solid and dark (e.g., R162613, R162615), in others there was only a slight stripe (R162514), or heavy mottling that obscured stripes (R162612). The border between lateral and ventral regions varied from a smooth transition with little marking (R162514), to a mottled transition zone (R162612, R162614), to a darker stripe (R162613, R162614). Mottling on posterior edge of thighs ranged from diffuse (e.g., R162614-5; as for holotype), to faint uniform stippling (R162612-3), or very faint stippling (R162514).

The two female specimens were similar in colouration - both had the dull reddish brown background colouration seen in several males, with moderate to heavy dark mottling on dorsal surface. Snout patches were less prominent and vertebral, dorsolateral and transverse bars weakly defined Female R162513 was lighter overall, including paler sides, no stippling on chin and only faint stippling on back of thighs (Figure 2D). Female R162620 was darker, with mottled sides, light stippling on chin and mottling on back of thighs similar to some males.

\section{Advertisement call}

The calls of the holotype male (R162611) and a paratype (R162612) were recorded on 30 January 2006 between 7 and $9 \mathrm{pm}$. The air temperature $1 \mathrm{~cm}$ above the males was $28.7^{\circ} \mathrm{C}$ (R162611) and $26.6^{\circ} \mathrm{C}$ (R162612), and the temperature of the flowing water about $5 \mathrm{~cm}$ below the surface was $-29^{\circ} \mathrm{C}$ for both.
The call of the holotype of L. staccato is presented in Figure 3C. It consists of a sequence of rapid, high-pitched, irregularly spaced, short (staccato) notes, followed by a series of softer and more widely spaced notes with occasionally more complex notes (Figure 3C-F). The holotype male called 3.8 times per minute with call duration averaging $6.5 \mathrm{~s}$ (maximum $-15 \mathrm{~s}$ ). Notes in the main call are irregularly spaced, sounding similar to a Morse code signal. There were an average of 25 notes/call and 4.3 notes/s. The notes increased slightly in amplitude during the call (Figure 3C). Each note consisted of a series of 14-19 pulses that increased in amplitude gradually with a sharper decrease, and with dominant frequencies of $2-3$ and $4-6 \mathrm{kHz}$ (Figure 3D). Between the main calls, the much less frequent softer calls were delivered in small clusters of typically 3-4 notes (up to six). These notes were made up of 5-8 pulses with dominant frequencies at 2, 3.5 and $5 \mathrm{kHz}$ (Figure $3 \mathrm{E})$. A third type of call was occasionally given among the softer calls that consisted of a rapid, trilllike series of modulated pulses with several peaks (Figure 3F). During the 10 minute recording, the male only began to give these more complex calls in the middle third of the calling sequence. These complex notes were made up of 34-48 pulses, had 4 or 5 peaks in amplitude during the brief $(0.15 \mathrm{~s})$ call and had dominant frequencies at 1.5 and $3.5 \mathrm{kHz}$.

The paratype male (R162612) had very similar call characteristics for the main call, but did not give the soft or complex calls between the main calls. These two individuals were calling on either side of a stream $>5 \mathrm{~m}$ apart. In both recordings, other males called simultaneously in response to each other. A gravid female (R162120) was captured within $2 \mathrm{~m}$ of R162612

\section{Breeding choruses}

Litoria staccato males called in choruses of 2-6 males in slow-flowing sections of a rocky creek at one site, and around shallow water in crevices or under boulders at another site located on an escarpment. Calling sites included exposed rocks, within crevices and under overhanging vegetation. One male (R162612) was observed calling $\sim 10 \mathrm{~cm}$ above the water (head facing down and towards the stream) while clinging vertically to a $\sim 50 \mathrm{~cm}$ boulder at the creek's edge. No males were observed to be within $5 \mathrm{~m}$ of each other and males often called from positions on opposite sides of the water body. Calls of males in breeding choruses occurred synchronously.

\section{Embryos}

A single clutch of embryos was collected that were either just prior to hatching or just hatched at stages 20-21 with capsules partly decomposed. The clutch was collected from a very small and shallow 

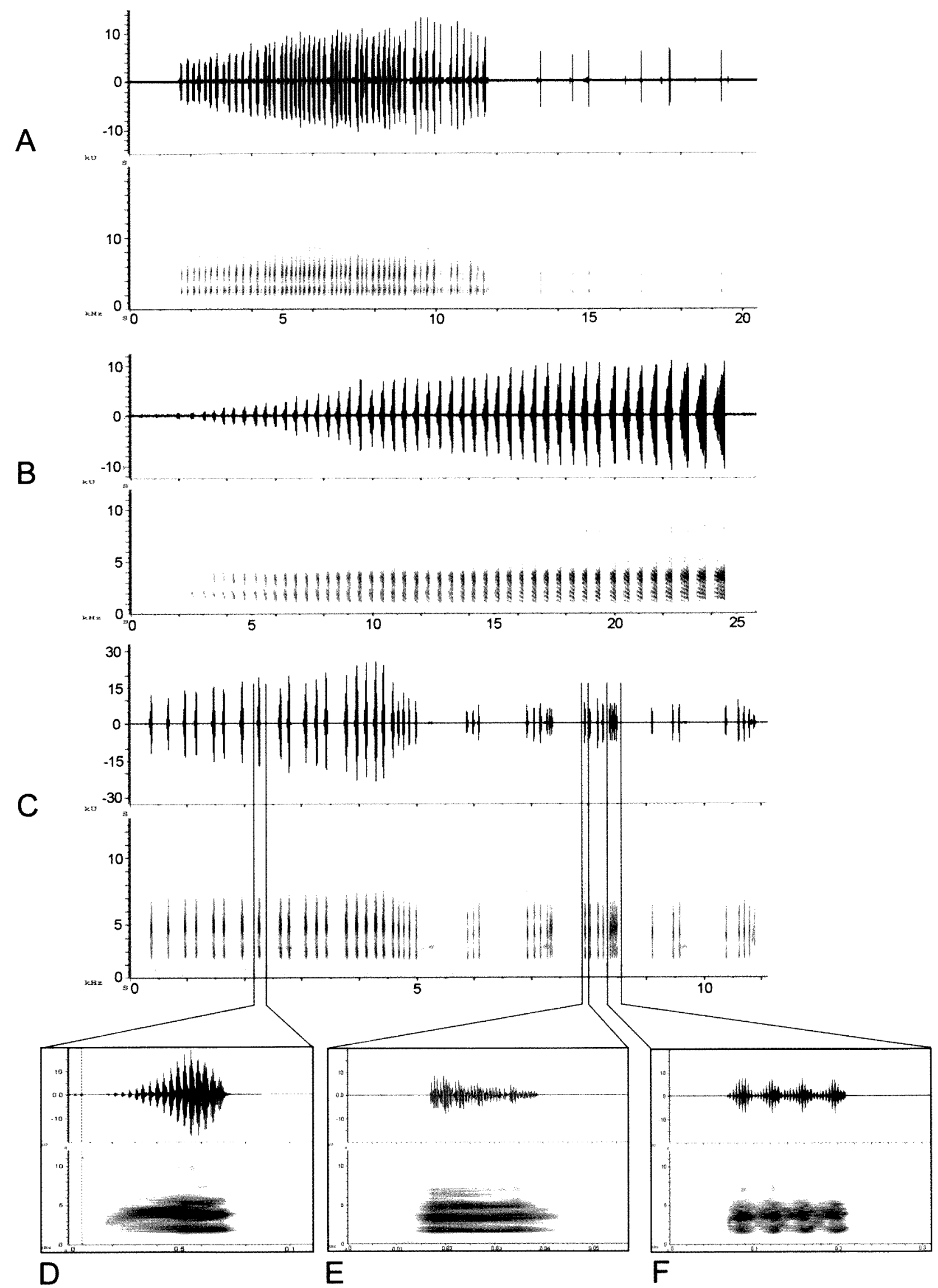

F

Figure 3 Oscillograms (upper) and sonograms (lower) of male advertisement calls. A) Litoria meiriana (WAM R162521); B) L. coplandi (uncollected); C) L. staccato holotype (WAM R162611); D) L. staccato main call; E) L. staccato soft call; F) L. staccato complex call. 
rock pool $(70 \times 30 \mathrm{~cm}$ and $2-3 \mathrm{~cm}$ deep) segregated by about two metres from the main creek, most of which was flowing at a reduced water level beneath large boulders. The pool contained leaf litter and tannin-stained water and was on a rock shelf where several calling males and a gravid female were found the previous night. The sample of small tadpoles collected at stages $26-27$ was taken from the same pool. The remaining jelly capsules were covered with silt and most were decomposing, but those of six embryos which had died earlier at about stages 13-14 were still intact, and these had a mean external capsule diameter of $3.83 \mathrm{~mm}$ (3.54$3.86 \mathrm{~mm})$.

Measurements of embryos are shown in Table 3. Two embryos at stage 20 had shorter gills, darker fins and a less arched dorsal fin than those at stage 21.

Stage 21 (Figure 4A). - Dorsum and tail muscle appear black macroscopically; area above head (lateral view) translucent grey; tail fins dusky grey; snout angular in lateral view; abdomen broad in dorsal view, yolk white; optic bulge discernable but barely pigmented; two pairs well developed external gills with 3-4 upper and 5-6 lower filaments; adhesive organs black and prominent; deep triangular stomodaeum bordered by labial ridges; narial pits visible.

Stage 23 (Figure 4B). - Reached on 10 January; dorsum very dark brown with scattered iridophores over snout, brain, eyes and tail muscle; yolk whitish with network of melanophores dorsolaterally; lateral line organs taintly visible; tail fins dusky grey, melanophores anteriorly across dorsal and partly lateral surface of muscle. Snout broad in dorsal view and rounded in lateral view; eyes well developed, cornea clear; external gills slightly reduced, upper and lower branches of similar length, 4-5 upper and 6-7 lower filaments; adhesive organs broad and flattened; nares perforated, opening anteriorly, quite widely spaced and situated right on tip of snout; labial ridges broader, upper ridge divided; jaw sheaths visible, keratin just visible on edge of upper sheath; operculum open on both sides, short tubular projection on edge of left side - juts outwards (probable early development of spiracle); tail fins well arched, tip broadly rounded; myotomes visible along muscle.

\section{Tadpoles}

The largest tadpole grew to a maximum total length of $52.0 \mathrm{~mm}$ and body length $17.5 \mathrm{~mm}$ (stage 38). Table 3 presents measurements of tadpoles. Tadpoles in captivity were predominantly bottom dwellers and mostly grazed on live algae on rocks and on sediments. Initially water was not aerated and while most tadpoles appeared to grow normally, some died. Aeration was then introduced and the remainder survived, became more agile and grew more steadily. Tadpoles frequently remained in the vicinity of the source of aeration, holding onto rocks with the oral disc. If disturbed, they rapidly darted under rocks or leaves.

Table 4 describes pigmentation development in life. In preservative, all golden, silver and copper iridophores are lost, together with lighter brown pigment, leaving only the darker melanophore patterns visible on the dorsum and tail. The venter

Table 3 Morphometric measurements of tadpoles of Litoria staccato, in $\mathrm{mm}$ (see Table 1B for abbreviations). Number of specimens: stages $20-21=7,25=2$, stages $26-29,32,38-40=1$, stage $36=3$, stage $46=2$.

\begin{tabular}{|c|c|c|c|c|c|c|c|c|c|c|c|c|c|c|}
\hline Stage & $20-21$ & 25 & 26 & 27 & 28 & 29 & 32 & 36 & 36 & 36 & 38 & 39 & 40 & 46 \\
\hline TL & $\begin{array}{c}5.72 \\
(5.24-5.98)\end{array}$ & $12.39,12.23$ & 20.0 & 21.5 & 26.0 & 29.0 & 35.0 & 42.6 & 40.5 & 44.0 & 52.0 & 49.0 & 48.3 & $17.5,19.0$ \\
\hline $\mathrm{BL}$ & & $4.99,4.99$ & 7.72 & 8.05 & 11.1 & 12.07 & 13.36 & 16.74 & 15.77 & 16.3 & 17.5 & 17.7 & 17.7 & \\
\hline $\mathrm{BD}$ & & & & & 6.15 & 6.76 & 7.24 & 9.01 & 8.69 & & & 9.98 & 9.66 & \\
\hline BW & & & & & 6.72 & 7.08 & 7.24 & 9.98 & 9.33 & & & 10.94 & 10.78 & \\
\hline EBW & & & & & 6.64 & 7.08 & 7.08 & 8.05 & 9.17 & & & 10.46 & 9.82 & \\
\hline ВТМ & & & & & 2.29 & 2.73 & 3.22 & 4.18 & 3.54 & & & 5.0 & 4.83 & \\
\hline BTMW & & & & & 2.09 & 2.41 & 2.57 & 3.54 & 3.7 & & & 5.15 & 5.15 & \\
\hline TD & & & & & 5.49 & 6.27 & 6.6 & 8.05 & 8.13 & & & 9.17 & 8.69 & \\
\hline DF & & & & & 1.88 & 2.09 & 2.25 & 2.57 & 2.65 & & & 2.98 & 3.05 & \\
\hline $\mathrm{TM}$ & & & & & 1.88 & 2.25 & 2.25 & 3.22 & 3.13 & & & 3.7 & 2.57 & \\
\hline$V F$ & & & & & 1.72 & 1.93 & 2.09 & 2.25 & 2.33 & & & 2.57 & 3.05 & \\
\hline 10 & & & & & 3.44 & 3.78 & 3.86 & 4.34 & 4.34 & & & 4.5 & 4.34 & \\
\hline IN & & & & & 1.88 & 2.09 & 2.09 & 2.57 & 2.57 & & & 2.57 & 2.57 & \\
\hline $\mathrm{EN}$ & & & & & 1.93 & 2.09 & 2.09 & 2.57 & 2.57 & & & 2.73 & 2.73 & \\
\hline$N$ & & & & & 0.28 & 0.28 & 0.32 & 0.3 & 0.32 & & & 0.32 & 0.32 & \\
\hline SS & & & & & 6.44 & 7.08 & 8.05 & 9.41 & 9.01 & & & 10.3 & 9.98 & \\
\hline SN & & & & & 1.28 & 1.28 & 1.61 & 2.01 & 1.61 & & & 2.25 & 1.61 & \\
\hline SE & & & & & 3.38 & 3.38 & 3.7 & 4.83 & 4.34 & & & 5.15 & 4.34 & \\
\hline ED & & & & & 1.36 & 1.45 & 1.93 & 2.09 & 2.25 & & & 2.57 & 2.57 & \\
\hline ODW & & & & & 3.19 & 3.28 & 3.36 & 4.18 & 3.93 & & & 4.51 & 4.67 & \\
\hline
\end{tabular}


A

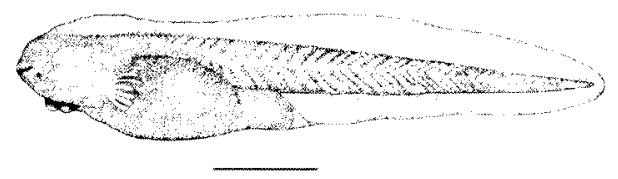

B
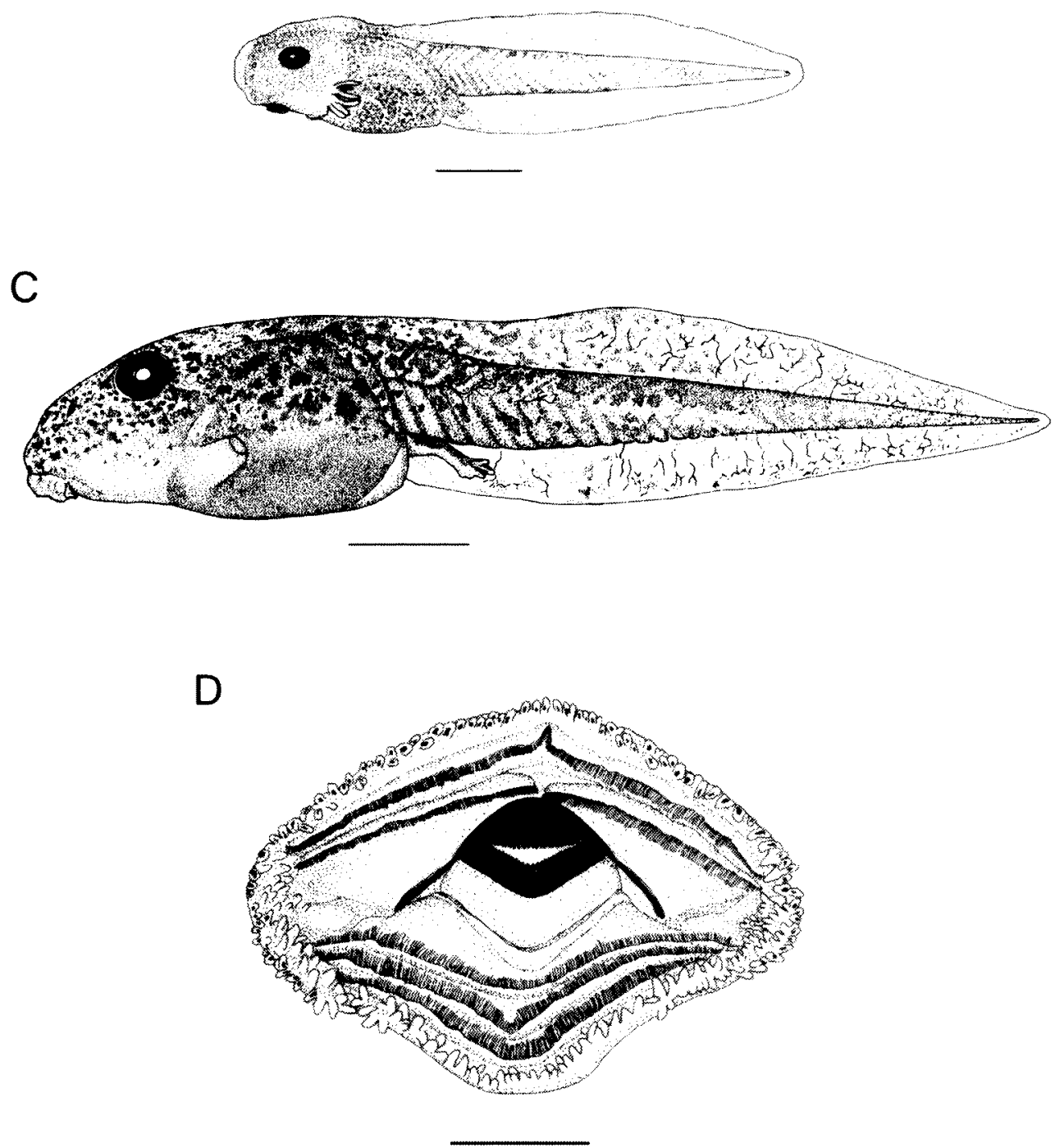

Figure 4 Embryos, tadpole and oral disc of Litoria staccato. A) hatchling at stage 20 , bar = $1 \mathrm{~mm}$; ) stage 23 , bar $=1$ $\mathrm{mm} ; \mathrm{C}$ ) tadpole at stage 36 , bar $=5 \mathrm{~mm}$; D) oral disc, specimen at stage 36 , bar $=1 \mathrm{~mm}$.

appears dark grey-blue and the paler snout colour is not visible. Description of the morphological changes during development are presented below.

Stage 25. - Reached by 14 January: body shape cylindrical, similar to Type 2 hylids (Anstis 2002); eyes near lateral; tail fins well arched, tail tip rounded.

Stages 26 and 27 (Figure 4A). - Mostly similar to later stages described below, apart from size and pigmentation changes (see below), in body features, mouthparts and tail features, but the distance from the eyes to the tip of the snout is shorter and the snout is a little narrower in dorsal view.
Stages 32-39. - Medium body size when full grown, as wide as deep across abdomen to about stage 32 , slightly wider than deep across abdomen from about stage 36 onwards; snout rounded in dorsal view, gradually becomes broader and slightly more streamlined anterior to eyes from about stage 34 onwards; eyes near lateral, slightly dorsolateral in later stages; nares small, quite widely spaced, open anterolaterally, slightly closer to tip of snout than to eyes; spiracle fairly short, broad, opens dorsoposteriorly below horizontal body axis posterior to midpoint of body; vent tube dextral (type a; Anstis 2002), narrow, and opens 
Table 4 Pigmentation of Litoria staccato tadpoles at different larval stages (Gosner 1960).

\begin{tabular}{|c|c|c|c|c|}
\hline Stage & Dorsum and Eyes & Sides & Venter & Tail \\
\hline 25 & $\begin{array}{l}\text { Melanophores over dorsum; } \\
\text { gold iridophores over most } \\
\text { of dorsum (except over } \\
\text { darker base of body); some } \\
\text { small dark patches over } \\
\text { vertebral region. }\end{array}$ & $\begin{array}{l}\text { Gold patch beginning on } \\
\text { each side of abdomen at } \\
\text { base of body, denser } \\
\text { iridophores posterior } \\
\text { to gill region. }\end{array}$ & $\begin{array}{l}\text { Mostly transparent, } \\
\text { bordered by dense } \\
\text { melanophores and } \\
\text { gold stippling. }\end{array}$ & $\begin{array}{l}\text { Fins clear, dorsal surface of } \\
\text { muscle dark, capped with } \\
\text { gold patches spaced along } \\
\text { length, lateral surface } \\
\text { stippled with melanophores, } \\
\text { a few gold iridophores } \\
\text { anteriorly. }\end{array}$ \\
\hline $\begin{array}{c}26-27 \\
(\mathrm{Fig} .5 \mathrm{~A})\end{array}$ & $\begin{array}{l}\text { Dorsum mostly uniform } \\
\text { golden; areas above brain, } \\
\text { around nares, over abdomen } \\
\text { and base of body a little } \\
\text { darker; iris golden above and } \\
\text { below pupil, black at each } \\
\text { side and across top. }\end{array}$ & $\begin{array}{l}\text { Gold clusters cover upper } \\
\text { half of abdomen, merging } \\
\text { down sides to orange- } \\
\text { gold, dark background } \\
\text { beneath; lower half of } \\
\text { abdomen orange-gold, } \\
\text { opaque white beneath; } \\
\text { orange-gold from gills to } \\
\text { eyes, clearer below; } \\
\text { distinct pale gold } \\
\text { longitudinal patch midway } \\
\text { down body along each side } \\
\text { of abdomen, just anterior } \\
\text { to base of body; another } \\
\text { similar but narrower } \\
\text { vertical patch just posterior } \\
\text { to gill region; pigment } \\
\text { lighter anteriorly. }\end{array}$ & $\begin{array}{l}\text { Brilliant orange-gold } \\
\text { over abdomen, } \\
\text { sparser over gills and } \\
\text { clear over buccal } \\
\text { region. }\end{array}$ & $\begin{array}{l}\text { fins mostly clear with some } \\
\text { dark veins; few gold specks } \\
\text { and melanophores on dorsal } \\
\text { fin; fine melanophores over } \\
\text { muscle anteriorly, gold } \\
\text { stippling dorsolaterally over } \\
\text { anterior third; lateral surface } \\
\text { of muscle mostly } \\
\text { unpigmented posteriorly; } \\
\text { some gold clusters anteriorly } \\
\text { over lower half. Anterior } \\
\text { edge of ventral fin bordered } \\
\text { with pale gold, gold clusters } \\
\text { over vent tube. }\end{array}$ \\
\hline $\begin{array}{c}32 \\
\text { (Fig. 5B) }\end{array}$ & $\begin{array}{l}\text { Dull golden brown or darker } \\
\text { brown with layer of fine } \\
\text { copper-gold iridophores over } \\
\text { most of head and body, dark } \\
\text { longitudinal stripe down } \\
\text { each side of vertebral region } \\
\text { and dark patch over base of } \\
\text { body, indistinct darker mask } \\
\text { bridges eyes. }\end{array}$ & $\begin{array}{l}\text { Distinct lateral gold bar } \\
\text { present at base of body } \\
\text { during at least stages } \\
26-28 \text { now mostly } \\
\text { obscured. }\end{array}$ & $\begin{array}{l}\text { Opaque silver-white } \\
\text { with copper sheen, } \\
\text { clearer below mouth. }\end{array}$ & $\begin{array}{l}\text { Diffuse melanophore clumps } \\
\text { over dorsal fin and muscle of } \\
\text { tail; few diffuse gold clusters } \\
\text { and flecks over muscle and } \\
\text { both fins; darker pigmented } \\
\text { veins over muscle and fins } \\
\text { (some outlined with gold). }\end{array}$ \\
\hline $\begin{array}{l}36-39 \\
(\mathrm{Fig} . \\
5 \mathrm{C}, \mathrm{D})\end{array}$ & $\begin{array}{l}\text { Diffuse melanophore clumps } \\
\text { over dorsal fin and muscle of } \\
\text { tail; a few diffuse gold clusters } \\
\text { and flecks over muscle and } \\
\text { both fins; darker pigmented } \\
\text { veins over muscle and fins } \\
\text { (some outlined with gold); } \\
\text { copper stripe extends from } \\
\text { middle of base of body just } \\
\text { onto dorsal surface of muscl; } \\
\text { dense copper-gold covers } \\
\text { most of iris. }\end{array}$ & $\begin{array}{l}\text { Mottling covers upper } \\
\text { two-thirds of body, } \\
\text { denser by stage } 38 \\
\text { onwards. }\end{array}$ & $\begin{array}{l}\text { Opaque silver right } \\
\text { up to mouth from } \\
\text { stage } 36 .\end{array}$ & $\begin{array}{l}\text { Darker mottling covers most } \\
\text { of tail; numerous pigmented } \\
\text { veins, some outlined with } \\
\text { gold; gold clusters anteriorly } \\
\text { on dorsal fin, copper-gold } \\
\text { along anterior edge of } \\
\text { ventral fin and over vent } \\
\text { tube; darker mottling denser } \\
\text { and covers entire tail by } \\
\text { stage } 38 \text {. }\end{array}$ \\
\hline $\begin{array}{c}42 \\
\text { (Fig. 5E) }\end{array}$ & $\begin{array}{l}\text { Pale triangle on snout anterior } \\
\text { to eyes visible, demarcated } \\
\text { posteriorly by diffuse darker } \\
\text { bar bridging eyes. }\end{array}$ & & & \\
\hline
\end{tabular}

posteriorly, dorsal edge partly unattached behind. Fins moderately arched and taper to somewhat elongate, narrowly rounded tip; dorsal fin begins just onto base of body, initially low then rises more distinctly to highest point anterior to midpoint of tail before tapering; ventral fin less arched.
Oral disc (Figure 4D). - Near ventral in direction in life (anterior medial margin tilts slightly upwards); ventral in preservative. Marginal papillae surround entire disc; anterior marginal papillae mostly in a single row medially to partway down lateral margins, increasing to two offset rows 

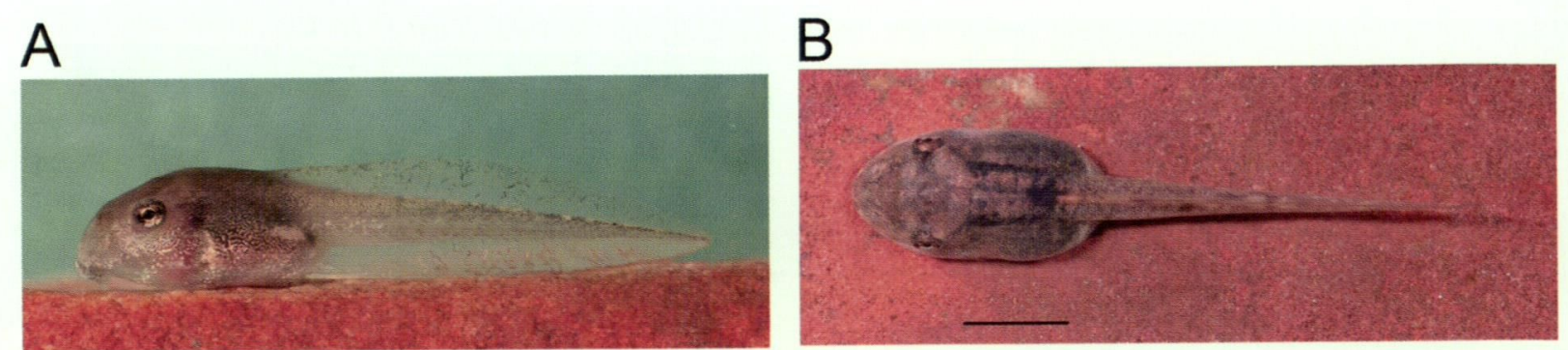

C

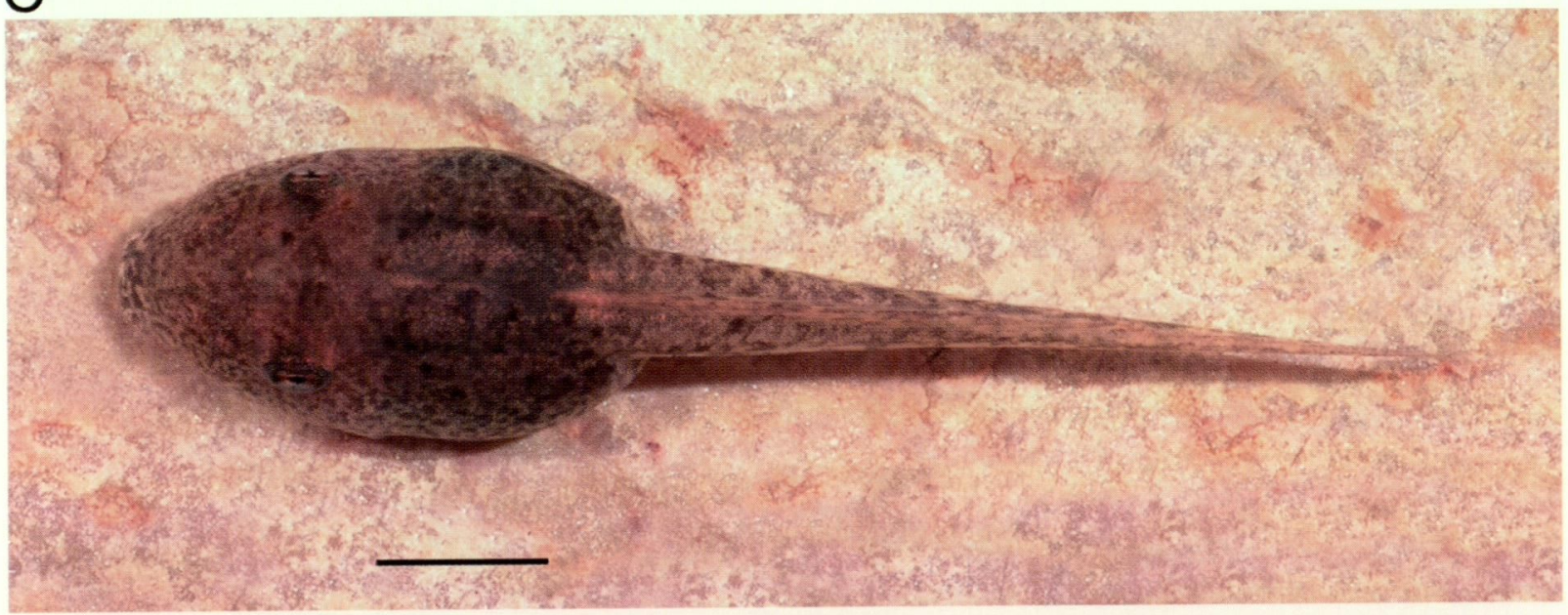

\section{D}

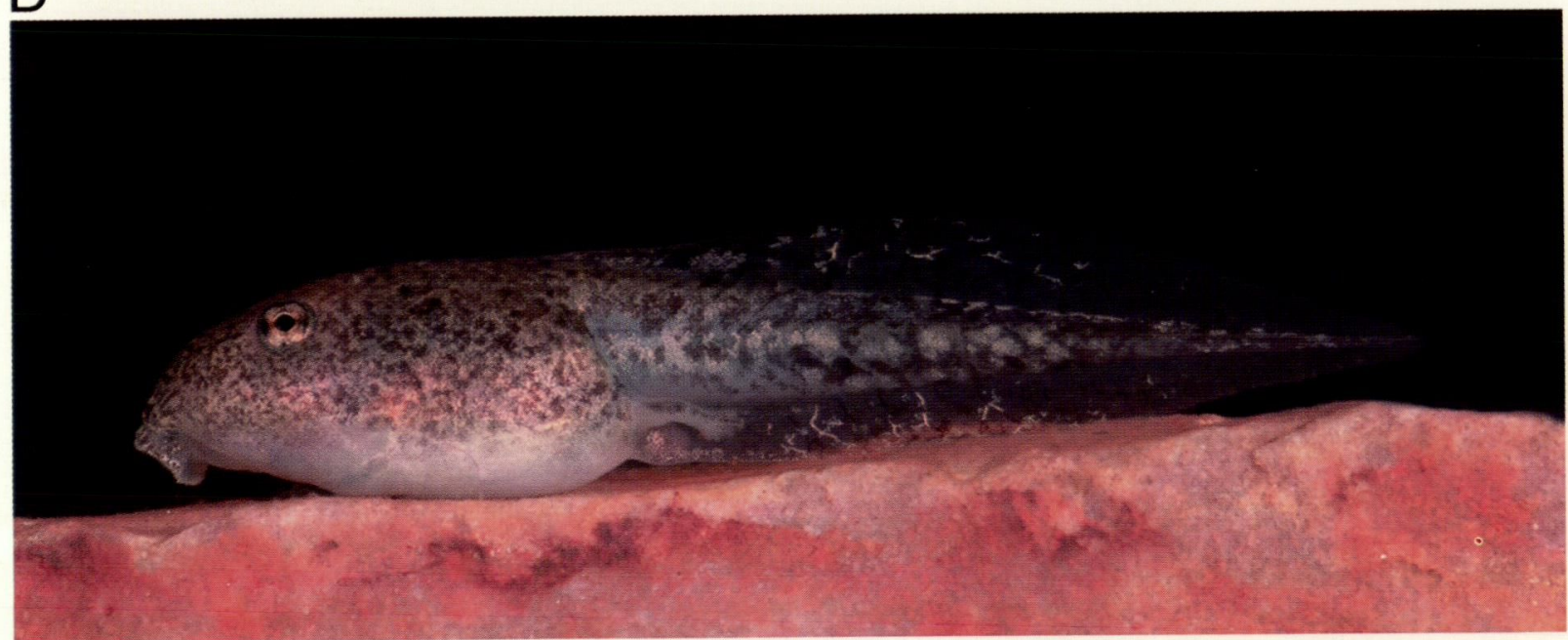

E

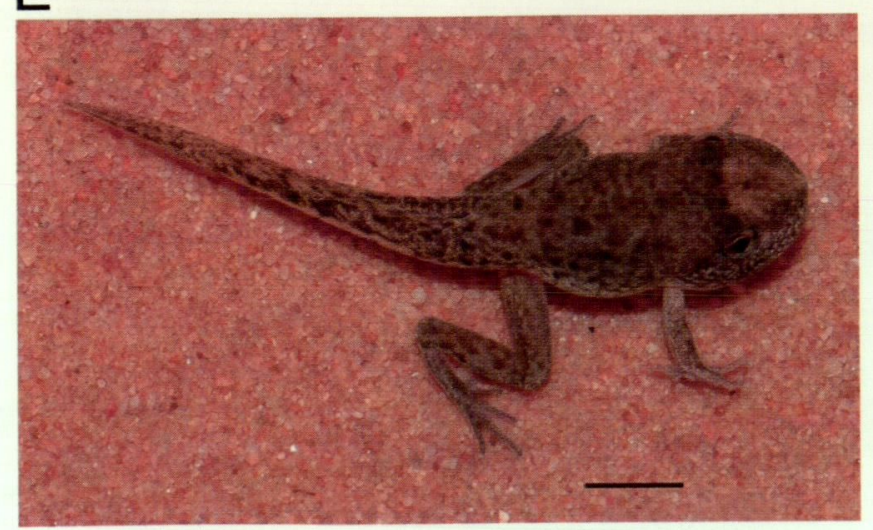

F

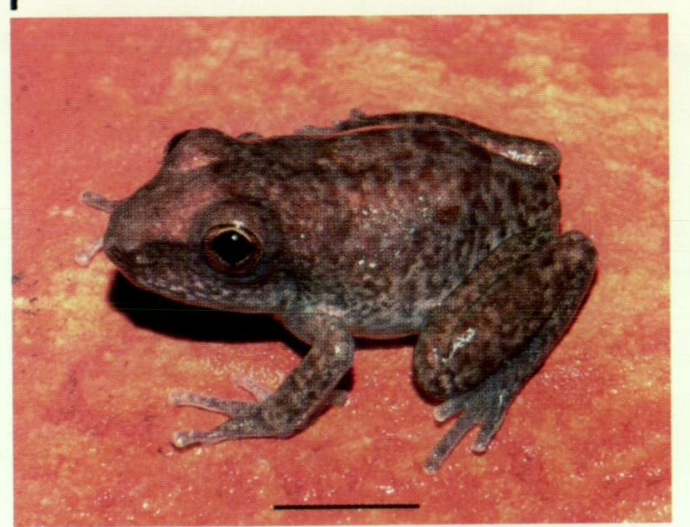

Figure 5 Live tadpoles and metamorph of Litoria staccato. A) stage 26 (lateral view); B) stage 32 (dorsal view); C, D) stage 36 (dorsal and lateral views); E) stage $42 ; \mathrm{F}$ ) stage 46 . Bar in each photo $=5 \mathrm{~mm}$. 
beyond this down each side of anterior half; some have as few as 10-25 medial papillae in a single row across top of disc before two rows begin on each side. Four to six rows of mostly small submarginal papillae at each side of disc; two rows offset slightly longer papillae around posterior margin; may be only one row initially at each side of margin, to up to three rows medially in some. Two anterior and three posterior tooth rows, $\mathrm{A}^{1}$ continuous, usually with medial pleat (Figure $5 B$ ), $A^{2}$ has a narrow medial gap, $P^{123}$ rows continuous, $P^{3}$ very slightly shorter. Jaw sheaths medium, quite distinctly serrated and fairly narrowly arched, with long flared lateral processes.

Metamorphosis. - Tadpoles collected at stage 26 on 9 January began to metamorphose on 11 February (33 d later), and hatchlings collected on 9 January first metamorphosed on 20 February (42 d later). Assuming that early development from egg to hatching is likely to take about $3 \mathrm{~d}$ in the shallow warm water of the initial pool, minimum larval life span in captivity for the hatchling group was about 45 d. Newly metamorphosed froglets had colouration similar to adults (Figure $5 \mathrm{~F}$ ). Head not quite as proportionately long yet as in adults. Terminal discs and webbing as for adults. Two newly metamorphosed froglets measured 17.5 and $19.0 \mathrm{~mm}$ SVL.

\section{Distribution}

Currently known from only two locations near "The Grotto", approximately $30 \mathrm{~km}$ south of Wyndham, Westem Australia (Figure 6). Both locations occur in the rocky southern portion of Parry's Lagoon Nature Reserve east of the Great Northern Highway. The entire collections of $L$. coplandi at the WA Museum (529 specimens), SA Museum (98 specimens), Museum and Art Gallery of the Northern Territory (190 specimens), Queensland Museum (77 specimens) and Australian Museum (151 specimens) were checked for the diagnostic characteristics of $L$. staccato. No specimens of $L$. staccato were detected. This indicates $L$. staccato's distribution is apparently restricted to the small area where the type series was collected. However, owing to the inaccessibility of the Kimberley region due to the rugged terrain and large areas with no vehicular access, it is likely that the new species will be found elsewhere in the eastern Kimberley, possibly to the northwest of the two known sites and to the east in the Northern Territory where similar habitats occur.

\section{Habitat}

Individuals of L. staccato were found in two areas with flowing water. The first was a steep rocky ridge with a slow trickle of water running under large boulders where males were calling, and where the eggs and tadpoles were collected (see above).
The second area (where the holotype was collected) was a creek that ran down a rocky ridge, about 2-3 $\mathrm{km}$ long (Figure 7). Both sources of water came from underground streams that flowed from near the top of ridges.

The vegetation at the rocky ridge sites where $L$. staccato occurs is sparse but dominated by Triodia wiseana with Cochlospermum fraseri, Calytrix exstipulata and stunted Erythrophlem chlorostachys. Along the watercourses where $L$. staccato was calling were Triodia pungens, Terminalia volucris, Ficus sp. and occasionally the boab tree Adansonia gregorii.

\section{Etymology}

Specific name 'staccato' is from the Italian musical term, and refers to the short detached sound of the individual repeated notes of the male advertisement call. It is to be treated as a noun in apposition.

\section{Comparison with other species}

\section{Adults}

In the eastern Kimberley, L. staccato may be potentially confused with several species of ground-dwelling Litoria which have pointed snouts, such as L. nasuta, L. pallida, L. inermis and L. tornieri. All of these species have narrow terminal discs on the fingers, whereas $L$. staccato has wider, expanded discs. Litoria nasuta has an elongate head with a strongly pointed snout and prominent longitudinal stripes. Litoria tornieri has a smooth dorsum, uniform pale body colour and a strongly contrasting dark lateral head stripe that breaks up posterior to the tympanum. Litoria inermis has a poorly defined lateral head stripe similar to $L$. staccato, but possesses raised tubercles over the dorsal surface, unlike the smooth skin of $L$. staccato. Although some L. pallida also possess a poorly defined lateral head stripe, they can be distinguished by very narrow terminal discs on the fingers, slightly raised tubercles on dorsum, distinctive penetrating call with much longer notes and selection of mostly still water breeding sites. Litoria wotjulumensis often breeds along rocky streams, has moderately expanded discs on the fingers and toes and also has a complex call with elements similar to $L$. staccato. However, $L$. wotjulumensis is a much larger species (almost double the length of $L$. staccato), has a more elongate head, possesses a strong, broad lateral head stripe and has fully webbed toes. Litoria meiriana also occurs along rocky creeks and rock holes and occurs in the Kimberley and Northern Territory. However, its most obvious difference from $L$. staccato is its much smaller size $(-20 \mathrm{~mm})$. In addition, L. meiriana is dorsoventrally compressed, has tubercular skin and fully webbed toes. 


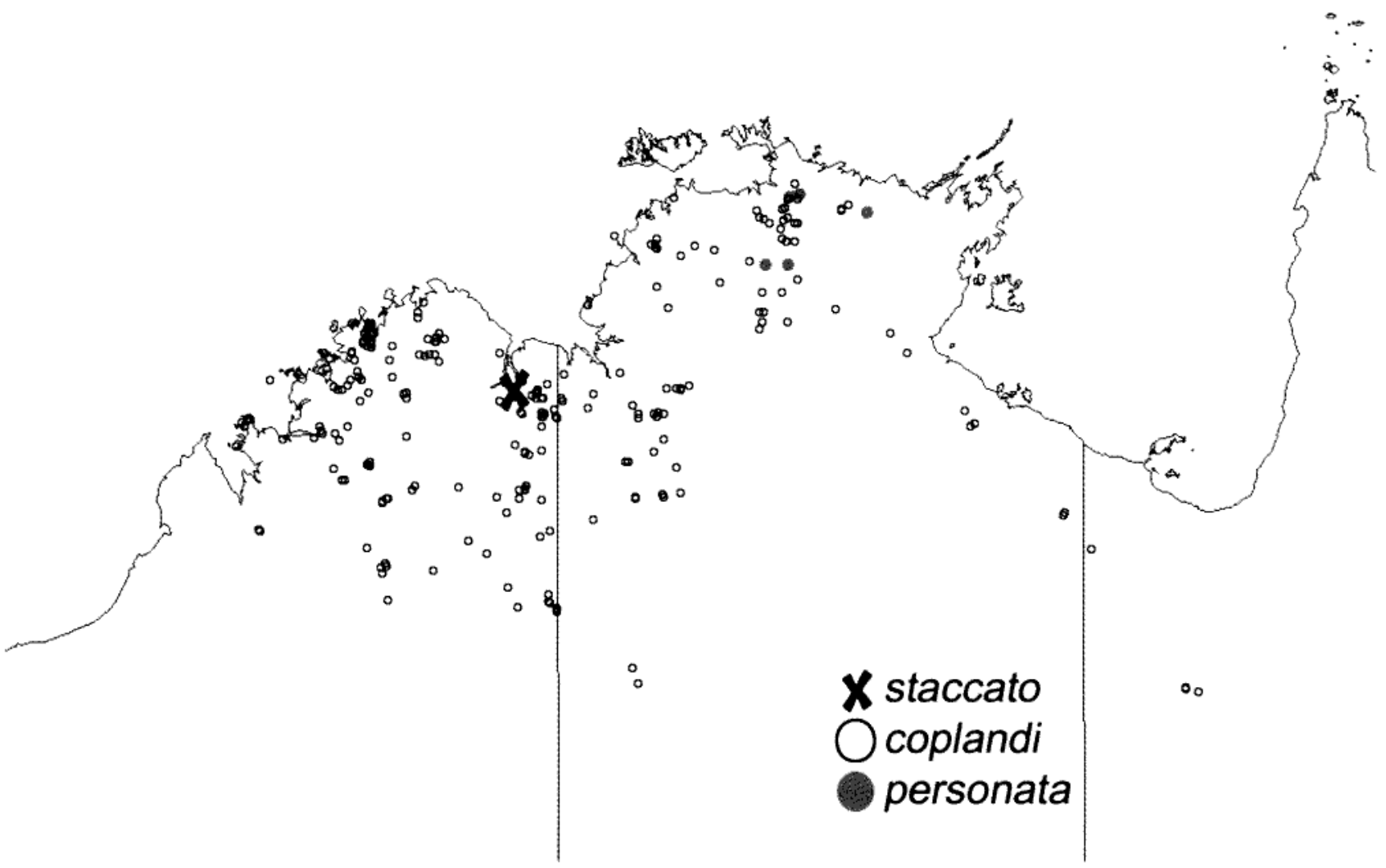

Figure 6 Distribution of Litoria coplandi, L. personata and L. staccato in northern Australia.

The two other rock-dwelling species with similar habits to $L$. staccato and thus most likely to be confused with it, are compared in more detail. Table 2 presents summaries of morphological measurements of $L$. staccato, $L$. coplandi and $L$. personata. Litoria coplandi reaches a larger body size, and females of both $L$. coplandi and $L$. staccato are larger than males. The relative head width of $L$. coplandi was wider than the other two species (Table 2). Hind limb proportions of $L$. coplandi and $L$. staccato were similar, but $L$. personata had longer hindlimbs. Thus, $L$. staccato is characterised by a narrower head relative to $L$. coplandi and shorter tibia and tarsus lengths compared to $L$. personata.

A number of other characters further distinguish these three rock-dwelling forms. The most reliable morphological character to distinguish the syntopic $L$. staccato and $L$. coplandi is the extent of webbing between the toes. In $L$. staccato the webbing is reduced, for example the distal two phalanges on the $4^{\text {th }}$ toe are free of webbing and the distal phalanges of the other toes are also free of webbing. In $L$. coplandi the webbing extends to the last phalanx on the $4^{\text {th }}$ toe and to the terminal discs on the remaining toes. The hands and feet of $L$. staccato are more gracile than the more heavily built $L$. coplandi. The webbing between the toes of $L$. personata is only slightly more extensive than $L$. staccato and much reduced relative to $L$. coplandi. Another consistent character among the three species is the glandular tissue at the angle of the jaw. This tissue is pronounced and raised into several discrete nodules in $L$. coplandi, much reduced in $L$. staccato (fewer and lower in profile) and absent in L. personata.

All three rock-dwelling hylids possess differences in dorsal colour and patterns that can be used to distinguish them, but these are individually variable and some are not retained or less evident in preservative. Ground colour of $L$. coplandi and $L$. personata ranges from light to medium brown, whereas $L$. staccato ranges from beige to slate grey to reddish brown (the majority of individuals). Litoria coplandi and $L$. personata have a relatively uniform dorsal colour. In contrast, many L. staccato individuals have more extensive mottling and possess variably expressed vertebral, dorsolateral and lateral stripes. The presence and prominence of a lateral head stripe is another way to separate them. Litoria personata has a strong, clearly defined lateral head stripe, $L$. staccato has a less prominent stripe with diffuse borders and $L$. coplandi lacks a lateral head stripe (unique in the $L$. lesueuri complex; Tyler 1968a; Barker et al. 1995).

\section{Advertisement call}

For the purposes of comparison, we present the calls of two sympatric rock-dwelling hylids for which no sonograms have been published, $L$. coplandi and $L$. meiriana (Figure 3A,B). Both males called within $5 \mathrm{~cm}$ of the edge of exposed rock 


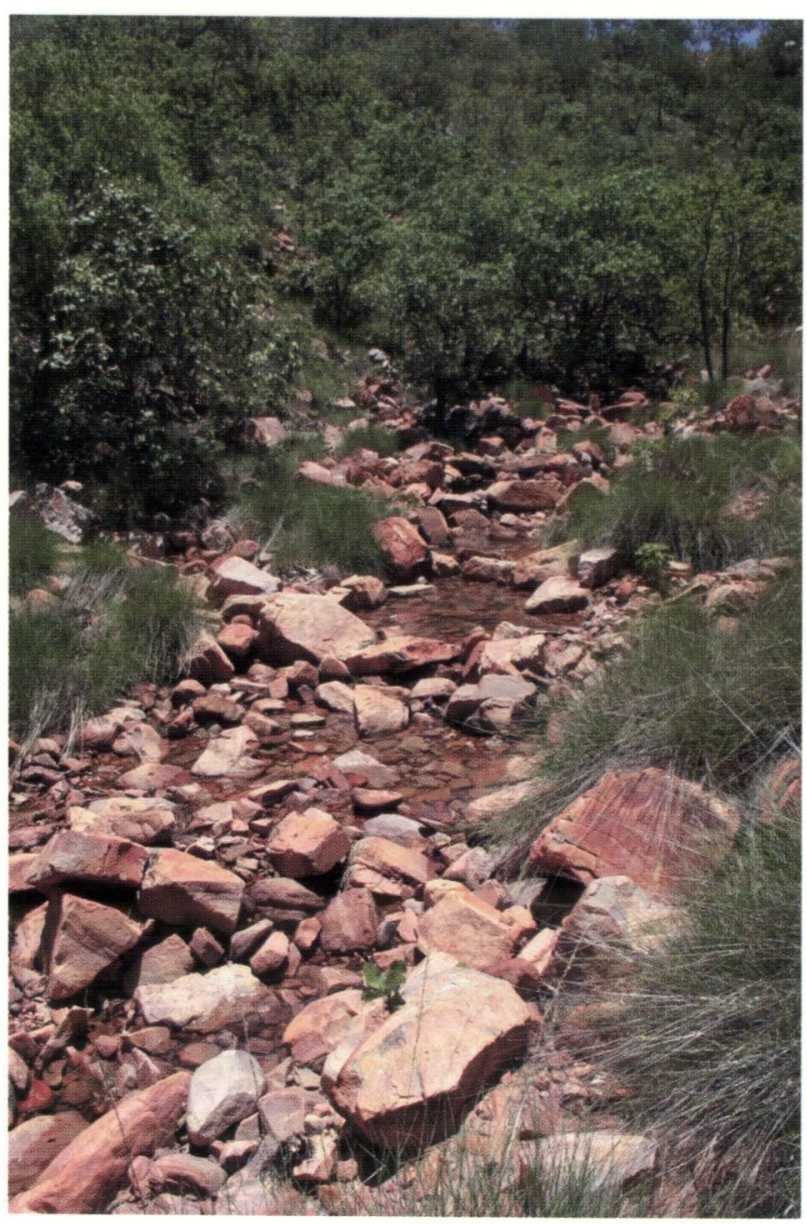

Figure 7 Type locality of Litoria staccato near Wyndham, Western Australia.

pools. The temperature $1 \mathrm{~cm}$ above the calling $L$. meiriana was $28.2^{\circ} \mathrm{C}$ with a water temperature of $32.1^{\circ} \mathrm{C}$; the $L$. coplandi male was recorded shortly after, and within $50 \mathrm{~m}$ of the L. meiriana male.

The call of $L$. meiriana is most similar to $L$. staccato owing to the notes of the main call being irregularly spaced (similar to Morse code). However, L. meiriana has a much higher-pitched call (dominant frequencies of 2-3 and 4-6 kHz) and the softer notes between main calls occur singly (Figure 3A), unlike in L. staccato (Figure 3C). The call of $L$. coplandi (Figure $3 \mathrm{~B}$ ) is easily distinguished by a combination of regularly-spaced notes, longer duration call (> $20 \mathrm{~s}$ ), main call begins very softly then increases steadily in amplitude, dominant frequencies of $1-2$ and $3-4 \mathrm{kHz}$ and single softer notes between main calls (as in $L$. meiriana).

The call of L. Wotjulumensis (not shown or analyzed) is highly distinctive and very complex (personal observations). The call contains loud, sustained sequences of calls that abruptly double in rate. The sustained calls can last for over $30 \mathrm{~s}$ and are usually followed by a series of complex trills, similar to the complex trill-like notes of L. staccato, but given more frequently. Owing to the few males that were recorded, our comparative results are best considered preliminary. More detailed sound analyses of more individuals and species is likely to yield additional differences between species and also provide estimates of variation within species. The calls of all species discussed above may be heard on www.museum.wa.gov.au/frogwatch.

\section{Eggs and tadpoles}

The remains of the egg mass collected indicate that eggs may be laid in fairly loose clumps attached to substrate rock. The eggs of $L$. coplandi also have been found laid on the floor of shallow rock pools singly or in small clumps (Tyler et al. 1983).

The tadpoles of L. staccato are distinguishable from $L$. coplandi as early as at stage 25 , when the mouthparts are complete, as L. coplandi tadpoles have two rows of continuous anterior papillae and L. staccato have only a single continuous row across part or all of the anterior margin. In addition, fully grown L. coplandi tadpoles have a more distinctly streamlined body form and a wider oral disc that appears to be slightly more suctorial than that of $L$. staccato. Of the other species of hylid tadpoles which are found in stream pools in the escarpment areas of the region, L. staccato have a generally similar body size and shape to those of $L$. inermis and L. wotjulumensis tadpoles, although they become slightly more streamlined anteriorly than $L$. inermis in later stages. Both $L$. inermis, $L$. wotjulumensis and all other known ground hylid species (with the exception of $L$. coplandi) in the Kimberley region of northern Australia have a narrow medial gap in the anterior papillae.

\section{Remarks}

New species of frogs are still being described in Australia, especially in the northern tropics and the eastern margin of the continent, where they are most diverse. Recent descriptions include the discovery of a highly distinctive stream-dwelling tree frog in north Queensland, L. andirrmalin (McDonald 1997), and a cryptic species of Uperoleia near Darwin, $U$. daviesae (Young et al. 2005). Genetic techniques and analysis of calls are resulting in further cryptic species being uncovered in frogs previously considered to be one species (e.g., L. lesueuri, which has now been split into three species, Donnellan and Mahoney 2004; see also Donnellan et al. 1983; Hoskin 2004).

The recent discovery of $L$. staccato highlights the possibility that more undescribed species of frogs may occur in the Kimberley region. Other than the sealed Great Northern Highway and the unsealed Gibb River Road, only the Mitchell Plateau has been reasonably sampled for frogs. Many surveys to other regions (e.g., Kendrick and Rolfe 1991) were designed to collect surface-active terrestrial 
vertebrates but did not specifically target frogs and did not involve night searches when breeding males are easily located by their calls. Future wet season frog surveys involving night work, recording of male calls and taking tissue samples for molecular analysis are likely to yield more undescribed species in the Kimberley Region.

Little is known of $L$. staccato. Breeding choruses occurred along rocky creeks up ridges or beside seeps running down rock faces. In the area near The Grotto where the type series was collected, several other species were calling. Calling from ponds on the flats between the ridges were the myobatrachids Crinia bilingua, Opisthodon ornatus, Notaden melanoscaphus and Uperoleia lithomoda, and the hylids Cyclorana australis, $C$. longipes, L. bicolor, L. pallida and L. nasuta. Calling along large flowing rocky creeks at the base of the ridges were $U$. borealis and $L$. wotjulumensis. Further up the ridge, calling males of $U$. borealis, Limnodynastes lignarius, Litoria coplandi and $L$. staccato occurred along small flowing rocky creeks. Near the top of the ridge, only Limnodynastes lignarius and Litoria staccato occurred. The reduced webbing on the feet of $L$. staccato (compared to $L$. coplandi) may indicate they are somewhat less aquatic, consistent with their distribution further up the two ridges than $L$. coplandi, where there is less water in creeks. Much more work is needed to gain a better understanding of the habits and distribution of $L$. staccato in the Kimberley region and possibly in adjacent parts of the Northern Territory.

\section{ACKNOWLEDGEMENTS}

We thank CALM "toadbusters" J. Francis and C. Mills for assistance in the field during the discovery and collection of the type series. G. Graham, G. McKae and the staff of CALM-Kununurra provided accommodation and logistical support for our surveys during the 2005-2006 wet season. We thank C. Stevenson (Western Australian Museum) for the drawings of the adults and the distribution map and J. Francis for the photograph of a calling male L. staccato (Figure 2C). Technical advice and loan of equipment for audio recordings and analysis were provided by J. D. Roberts (University of Western Australia) and C. Gerhardt (University of Missouri). We thank P. Horner (Museum and Art Gallery of the Northern Territory), P. Couper (Queensland Museum) and M. Hutchinson (South Australian Museum) for loan of specimens, and S. Reynolds (Charles Darwin University) and P. Oliver (Adelaide University) for searching through the $L$. coplandi collections for specimens of the new species. This work was made possible through the Western Australian Museum's Alcoa Frog Watch programme funded by Alcoa of Australia. This paper is dedicated to the volunteer "toadbusters" of the Kununurra community.

\section{REFERENCES}

Anstis, M. (2002). Tadpoles of south-eastern Australia: a guide with keys. Reed New Holland, Sydney, NSW.

Anstis, M. and Tyler, M. J. (2005). Breeding biology of Litoria microbelos (Cogger) (Anura: Hylidae). Transactions of the Royal Society of South Austalia 129: $43-48$.

Barker, J., Grigg, G. C. and Tyler, M. J. (1995). A Field Guide to Australian Frogs. Surrey Beatty \& Sons, Chipping Norton, NSW.

Charif, R. A., Clark, C. W. and Fristrup, K. M. (2004). Raven 1.2 User's Manual. Cornell Laboratory of Ornithology, Ithaca, NY, USA.

Donnellan, S., Adams, M., Hutchinson, M. and Baverstock, P. R. (1993). The identification of cryptic species in the Australian herpetofauna: a high research priority (pp. 121-125). In Lunney, D. and Ayers, D. (eds.) Herpetology in Australia: a diverse discipline. Surrey Beatty \& Sons, Chipping Norton, NSW, Australia.

Donnellan, S. C. and Mahoney, M. I. (2004). Allozyme, chromosomal and morphological variability in the Litoria lesueuri species group (Anura: Hylidae), including a description of a new species. Australian Journal of Zoology 52:1-28.

Gosner, K. L. (1960). A simplified table for staging anuran embryos and larvae with notes on identification. Herpetologica 16:183-190.

Hoskin, C. J. (2004). Australian microhylid frogs (Cophixalus and Austrochaperina): phylogeny, taxonomy, calls, distributions and breeding biology. Australian Journal of Zoology 52:237-269.

Kendrick, P. G. and Rolfe, J. K. (1991). The reptiles and amphibians of Kimberley rainforests (pp. 347-359). In McKenzie, N. L., Johnston, R. B. and Kendrick, P. G. (eds.) Kimberly Rainforests of Australia. Surrey Beatty \& Sons, Chipping Norton, NSW.

McDonald, K. R. (1997). A new stream-dwelling Litoria from the Melville Range, Queensland, Australia. Memoirs of the Queensland Museum 42:307-309.

Tyler, M. J. (1968a). A taxonomic study of hylid frogs of the Hyla lesueuri complex occurring in north-western Australia. Records of the South Australian Museum 15:711-727.

Tyler, M. J. (1968b). Papuan hylid frogs of the genus Hyla. Zoologishce Verhhandelingen 96:1-203.

Tyler, M. J. and Davies, M. (1978). Species groups within the Australopapuan hylid frog genus Litoria Tschudi. Australian Joumal of Zoology 63 (supplement): 1-47.

Tyler, M. J., Davies, M. and Martin, A. A. (1978). A new species of hylid frog from the Northern Territory. Transactions of the Royal Society of South Australia 102:151-157.

Tyler, M. J., Crook, G. A. and Davies, M. (1983). Reproductive biology of the frogs of the Magela Creek system, Northern Territory. Records of the South Australian Museum 18: 415-440. 
Young, J. E., Tyler, M. J, and Kent, S. A. (2005). Diminutive new species of Uperoleia Grey (Anura: Myobatrachidae) from the vicinity of Darwin, Northern Territory, Australia. Journal of Herpetology 39: 603-609.

Manuscript recened 25July 2006; accepted 18 October 2006

\section{APPENDIX}

Comparative material examined.

Abbreviations: SAM - South Australian Museum; NT - Museum and Art Gallery of the Northern Territory; QM - Queensland Museum; note specimen numbers without one of these prefixes are from the Western Australian Museum.

\section{Litoria coplandi}

Males - WAM R103060, R108792, R110746, R114039, R114090, R119091, R114092, R129193, R137838, R137384，R137385, R140357, R140362, R152951，R162520，R162523，R162524，R162535, R162536, R162539, R162547, R162548, R162549, R162950, R162581，R162596, R162597, R162602, R162603, R162609, R162610, QM J54933, QM J56592, QM J56588, QM J56595, QM J56580.

Females - R97942, R114088, R127332, R137382, R137389, R138879, R138883, R138894, R140351, R140352, R140361, R140369, QM J53809, QM J56584, QM J56596.

Juveniles (sex unknown) - R95599, R129194, R95509, R87922.

\section{Litoria personata}

Males - NT R16886, NT R18794, NT R18795, NT R19807, NT R19809, NT R20466, SAM R16773, SAM R16774.

Females - NT R20467, NT R20468, SAM R16831, SAM R16832.

Juvenile - SAM R16829.

\section{Note added in proof.}

Field trips in 2006-2007 have recorded L. staccato from the Mitchell Plateau and Prince Regent Nature Reserve, greatly extending its distribution. 